\title{
Effect of Integrated Nutrient Management on Soil Properties, Yield Attributes and Yield of Wheat (Triticum aestivum L.)
}

\author{
Abhimanyu Yadav ${ }^{1}$, Adesh Kumar ${ }^{1 *}$, Ved Prakash ${ }^{1}$, Neeraj Kumar ${ }^{1}$, \\ Ashutosh Tiwari ${ }^{2}$ and R.K. Yadav ${ }^{3}$ \\ ${ }^{1}$ Department of Soil Science and Agricultural Chemistry, ${ }^{2}$ Department of Plant Biotechnology, \\ ${ }^{3}$ Department of Crop Physiology, N.D. University of Agriculture and Technology, Narendra \\ Nagar (Kumarganj) Faizabad -224 229 (U.P.), India
}

*Corresponding author

\begin{tabular}{|c|c|}
\hline & A B S T R A C T \\
\hline Keywords & \multirow{6}{*}{$\begin{array}{l}\text { A field experiment was conducted during winter season of } 2014-15 \text { on wheat at } \\
\text { Instructional Farm of Narendra Deva University of Agriculture and Technology, } \\
\text { Kumarganj, Faizabad (UP). The soil of the experimental field was silt loam having pH } \\
8.25, \mathrm{EC} 0.35 \mathrm{dSm}^{-1} \text {, organic carbon } 4.4 \mathrm{~g} \mathrm{Kg}^{-1} \text { available nitrogen } 195 \mathrm{Kg} \mathrm{ha}^{-1} \text {, available } \mathrm{P} \\
12 \mathrm{Kg} \mathrm{ha}^{-1} \text { and available K } 240 \mathrm{Kg}^{-1} \text { he experiment was consisted of } 8 \text { treatments viz. } \mathrm{T}_{1} \\
\text { (control), } \mathrm{T}_{2}(100 \% \mathrm{RDF}), \mathrm{T}_{3}(75 \% \mathrm{RDF}), \mathrm{T}_{4}(75 \% \mathrm{RDF}+25 \% \mathrm{~N}-\mathrm{FYM}), \mathrm{T}_{5}(75 \% \\
\mathrm{RDF}+\text { Azotobacter), } \mathrm{T}_{6}(50 \% \mathrm{RDF}+50 \% \mathrm{~N}-\mathrm{FYM}) \mathrm{T}_{7}(50 \% \mathrm{RDF}+50 \% \mathrm{~N}-\mathrm{FYM}+ \\
\mathrm{PSB}) \text { and } \mathrm{T}_{8}(50 \% \mathrm{RDF}+\text { Azotobacter }+\mathrm{PSB}) \text { were laid in the randomized block design } \\
\text { with three replication. The highest values of yield and yield attributes were recorded with } \\
\text { treatment } \mathrm{T}_{7}(50 \% \mathrm{RDF}+50 \% \mathrm{~N}-\mathrm{FYM}+\mathrm{PSB}) \text { which was significantly superior over } \\
\text { control as well as } \mathrm{T}_{3}(75 \% \mathrm{RDF}), \mathrm{T}_{5}\left(75 \% \mathrm{RDF}+\text { Azotobacter) and } \mathrm{T}_{8}(50 \% \mathrm{RDF}+\right. \\
\text { Azotobacter }+\mathrm{PSB} \text { ) and statistically at par with rest of the treatments. }\end{array}$} \\
\hline & \\
\hline & \\
\hline Soil p & \\
\hline Article Info & \\
\hline $\begin{array}{l}\text { Accepted: } \\
\text { 04 September } 2017 \\
\text { Available Online: } \\
10 \text { October } 2017\end{array}$ & \\
\hline
\end{tabular}

\section{Introduction}

Wheat (Triticum aestivum L.) is one of the most important cereal crops of the world. Among the world's most important food grains, it ranks next to rice. It is eaten in various forms by more than one billion in the world. Millions of farmer in developing countries need adequate resource for augmenting crop productivity and sustainability of soil. Therefore to maintain fertility and productivity of soil at sustainable level for long duration, there is need to adopt the concept of integrated nutrient management. Organic manure such as farm yard manure, vermin-compost, crop residues, biofertilizer, green manure and chemical fertilizer are considered to be an integral component of integrated nutrient management and may help to recover soil health in cropping system. As they improve soil fertility and physical properties such as soil structure, aeration, porosity, infiltration rate and water holding capacity and decrease soil crusting, organic matter in soil improve physical condition of the soil for better performance of micro-organism and physical status of soil. Organic matter affects crop 
growth and yields either directly supplying nutrients or indirectly by modifying soil physical properties such as stability of aggregates, porosity and available water capacity that can improve the root environment and stimulate plant growth. Organic matter not only increases the water holding capacity of the soil but also proportion of water available for plant growth and improves physical properties of soil (Sial et al., 2007).

\section{Materials and Methods}

A field experiment was conducted during winter season of 2014-15 in silt loam soil at instructional farm of Narendra Deva University of Agriculture and technology Kumarganj, Faizabad $\left(26.47^{0} \mathrm{~N}\right.$ and $\left.82.12^{0} \mathrm{E}\right)$. Initial soil characteristics $(0-15 \mathrm{~cm})$ of the experimental soil were $\mathrm{pH} 8.25$ (1:2.5 soil and water suspension), electrical conductivity $0.35 \mathrm{dSm}^{-1}$ organic carbon $4.40 \mathrm{gm} \mathrm{kg}^{-1}$, available $\mathrm{N} \mathrm{kg} \mathrm{ha}{ }^{-1}$, available $\mathrm{P} 12 \mathrm{~kg} \mathrm{ha}^{-1}$, available $\mathrm{K} 240 \mathrm{~kg} \mathrm{ha}{ }^{-1}$. The treatment consisted of $\mathrm{T}_{1}$ control, $\mathrm{T}_{2} \quad 100 \%$ RDF (120:60:40 kg ha $\left.{ }^{-1} \mathrm{~N}: \mathrm{P}_{2} \mathrm{O}_{5}: \mathrm{k}_{2} \mathrm{O}\right) ; \mathrm{T}_{3}, 75 \%$ RDF, T4 $75 \%$ RDF + $25 \%$ N-FYM, T , $75 \%$ RDF+ Bio-fertilizer (Azotobactor); $\mathrm{T}_{6}$ $50 \% \mathrm{RDF}+50 \% \mathrm{~N}-\mathrm{FYM}, \mathrm{T}_{7}(50 \% \mathrm{RDF}+$ $50 \% \mathrm{~N}-\mathrm{FYM}+\mathrm{PSB})$ and $\mathrm{T}_{8} 50 \% \mathrm{RDF}+$ Azotobacter + PSB. The experiment was laid out in a randomized block design with 3 replications. FYM was applied as per treatment one week prior to pre-sowing irrigation. Wheat crop (CV NW 2036) was sown at proper moisture on first Dec. 2014 at a row spacing of $20 \mathrm{~cm}$. Half of $\mathrm{N}$ and full doses of $\mathrm{P}$ and $\mathrm{K}$ were added at the time of sowing as per treatments. The remaining dose of $\mathrm{N}$ was top dressed in two equal splits after $1^{\text {st }}$ and $2^{\text {nd }}$ irrigation. The sources of $\mathrm{N}, \mathrm{PO}_{5}$ and $\mathrm{K}_{2} \mathrm{O}$ were urea, single super phosphate and mutate of potash respectively. Plant height was recorded at 30,60, and 90 DAS. Yield and yield attributes were recorded at harvest. Soil samples collected before sowing and after harvest of wheat were analyzed for $\mathrm{pH}$ and $\mathrm{EC}$ in 1:2.5 soil water suspension; organic carbon, available $\mathrm{N}$, available $\mathrm{P}$ and available K (Jackson, 1973).

\section{Results and Discussion}

Various levels of nutrients applied through fertilizers alone and their combination with FYM and bio-fertilizers influenced the plant height significantly. It is further evident from the perusal of data that the highest plant height $(93.2 \mathrm{~cm})$ was recorded under the treatment $\mathrm{T}_{7}(50 \% \mathrm{RDF}+50 \% \mathrm{~N}-\mathrm{FYM}+$ PSB) and minimum $(60.4 \mathrm{~cm})$ in $\mathrm{T}_{1}$ (control) at harvest stage.

The increase in plant height under various inorganic fertilizer levels alone and in combination with organic sources might be due to increasing availability of nutrients to the plants. The results are in harmony with findings of Khan et al., (2007) as well as Soleimanzadeh and Gooshchi (2013)

The data presented in table 1 revealed that maximum number of effective tillers (92.6), grains ear $^{-1}(61.6)$ and test weight (36.6) were recorded under treatment $\mathrm{T}_{7}(50 \%$ $\mathrm{RDF}+50 \% \mathrm{~N}-\mathrm{FYM}+\mathrm{PSB})$ which was statistically at par with $\mathrm{T}_{2}(100 \% \mathrm{RDF}), \mathrm{T}_{4}$ (75\% RDF + $25 \% \mathrm{~N}-\mathrm{FYM}$ and $\mathrm{T}_{6}(50 \%$ $\mathrm{RDF}+50 \% \mathrm{~N}-\mathrm{FYM}$ ) while least in $\mathrm{T}_{1}$ (control). The test weight was nonsignificant and not affected by various treatments. Similar results have been reported by Devi et al., (2011). Maximum grain and straw yields were recorded under treatment $\mathrm{T}_{7}-50 \% \mathrm{RDF}+50 \% \mathrm{~N}-\mathrm{FYM}+$ PSB which was statistically at par with T2 (100\% RDF) T6 (50\% RDF + $50 \% \mathrm{~N}-$ FYM) and T4 (75\% RDF + $25 \%$ N-FYM) and significantly superior over rest of the treatments. The results corroborated with observations taken by Devi et al., (2011). 
Table.1 Effect of treatments on growth, yield attributes and yields of wheat

\begin{tabular}{|l|c|c|c|c|c|c|}
\hline Treatments & Plant & Effective & Grains & Test & \multicolumn{2}{|c|}{ Yield qha-1 } \\
\cline { 6 - 7 } & height $(\mathrm{cm})$ & tillers $(\mathrm{m}-1)$ & ear-1 & weight & Grain & Straw \\
\hline T1 & 60.4 & 80.0 & 34.0 & 35.8 & 17.9 & 26.5 \\
\hline T2 & 93.0 & 90.5 & 60.5 & 36.6 & 41.6 & 60.3 \\
\hline T3 & 82.5 & 84.4 & 52.2 & 36.4 & 32.8 & 49.1 \\
\hline T4 & 91.6 & 88.0 & 59.0 & 36.6 & 39.6 & 57.0 \\
\hline T5 & 84.1 & 86.6 & 55.4 & 36.5 & 35.6 & 53.0 \\
\hline T6 & 92.1 & 89.8 & 59.7 & 36.6 & 39.9 & 57.2 \\
\hline T7 & 93.2 & 92.6 & 61.6 & 36.6 & 41.9 & 60.7 \\
\hline T8 & 81.1 & 86.0 & 55.0 & 36.3 & 34.8 & 51.8 \\
\hline SEm & 3.02 & 1.30 & 1.99 & 0.18 & 1.11 & 2.42 \\
\hline CD $(\mathrm{p}=0.05)$ & 9.11 & 3.80 & 6.05 & 0.51 & 3.35 & 7.36 \\
\hline
\end{tabular}

Table.2 Effect of INM treatments on $\mathrm{pH}, \mathrm{EC}$, organic carbon and available nutrients in Post-harvest soil

\begin{tabular}{|l|c|c|c|c|c|c|}
\hline Treatments & $\mathrm{pH}$ & EC $(\mathrm{dSm}-1)$ & \multirow{2}{*}{$\begin{array}{c}\text { OC } \\
(\mathrm{gKg}-1)\end{array}$} & \multicolumn{3}{|c|}{ Available nutrients $\left(\mathrm{kgha}^{-1}\right)$} \\
\cline { 5 - 7 } & & & 3.1 & 180.2 & 11.0 & 200.0 \\
\hline T1 & 8.30 & 0.29 & 3.3 & 194.2 & 12.2 & 213.6 \\
\hline T2 & 8.26 & 0.29 & 3.2 & 185.6 & 12.1 & 210.1 \\
\hline T3 & 8.28 & 0.29 & 3.5 & 1927 & 12.4 & 213.6 \\
\hline T4 & 8.24 & 0.27 & 3.3 & 189.9 & 12.4 & 210.7 \\
\hline T5 & 8.29 & 0.30 & 3.8 & 195.2 & 12.3 & 215.5 \\
\hline T6 & 8.20 & 0.25 & 3.8 & 195.2 & 12.4 & 215.5 \\
\hline T7 & 8.20 & 0.25 & 3.3 & 187.8 & 12.2 & 208.9 \\
\hline T8 & 8.28 & 0.30 & 0.1 & 2.3 & 0.12 & 2.58 \\
\hline SEm & 0.11 & 0.01 & 0.3 & 7.2 & 0.35 & 7.83 \\
\hline CD $(\mathrm{p}=0.05)$ & NS & NS & 0.3 & & & \\
\hline
\end{tabular}

It is due to more supply of $\mathrm{P}_{2} \mathrm{O}_{5}$, helps in maintaining better source-sink inter relationship by increasing sink capacity by its role in energy transformation. Various INM treatments could not decrease the $\mathrm{pH}$ and $\mathrm{EC}$ of post-harvest soil significantly.

The higher buildup of organic carbon (3.8 gm $\left.\mathrm{kg}^{-1}\right)$ was noted in $\mathrm{T}-7$ (50\% RDF $+50 \% \mathrm{~N}-$ $\mathrm{FYM}+\mathrm{PSB})$ as well as in T-6 (50\% RDF + $50 \%$ N- FYM) which was statistically at par with T-4 (75\% RDF $+25 \%$ N-FYM) and significantly superior over rest of the treatment.The buildup of organic carbon must be due to addition of FYM. Similar result was also reported by Mohemmmed et al., (2014) and Eldardiry et al., (2013).

Maximum available N (195.2 $\left.\mathrm{kg} \mathrm{ha}^{-1}\right)$ was recorded in the treatment $\mathrm{T}-7$ (50\% $\mathrm{RDF}+$ $50 \% \mathrm{~N}-\mathrm{FYM}+\mathrm{PSB})$ as well as in T-6 (50\% $\mathrm{RDF}+50 \% \mathrm{~N}-$ FYM) which was significantly superior over $\mathrm{T}_{3}(70 \% \mathrm{RDF})$ as well as control and statistically at par with rest of the treatments. Maximum available $\mathrm{P}$ $\left(12.45 \mathrm{~kg} \mathrm{ha}^{-1}\right)$ was recorded on the treatment T-7 (50\% RDF +50\% N- FYM + PSB) which was significantly superior over control and statistically at par with rest of the treatments. Similar trend in available potash was also 
noted as in table 2 . The result exhibited that the INM through organic and inorganic fertilizer used in suitable combination improved the soil fertility. The present findings are in conformity with findings of Kumar (2014), Davari et al., (2012) and Essan and Lattief (2014).

\section{References}

Davari, M.R., Sharma S.N. and Mirzakhani M. 2012. The effect of combinations of organic materials on productivity, grain quality, nutrient uptake and economics in organic farming wheat. Journal of Organic Systems, 7(2):26-35.

Devi, K.N., Singh M.S., Singh. G. and Athokpam H.S. 2011. Effect of integrated nutrient management on growth and yield of wheat (Triticum aestivum L.). Journal of Crop and Weed, 7 (2): 23-27.

Eldardiry, E., Hellal F., Mansour H. and Hady M.A.E 2013. Assessment cultivated period and farm yard manure addition in some soil properties, nutrient content and wheat yield under sprinkler system. Agricultural Sciences 4(1)14-22.

Essam, A., and Lattief AE 2014. Influence of integrated nutrient management on productivity and grain protein content of wheat under sandy soils conditions. Biolife Journal, 2(4): 1359-1364.
Jackson, M.L., 1973. Soil chemical analysis Prentice Hall of India, Pvt. Ltd. New Delhi.

Khan, M.U., Qasim M. and Khan I U 2007. Effect of integrated nutrient management on crop yields in rice wheat cropping system. Sarhad Journal of Agriculture, 23(4):1019-1026

Kumar, D., 2014. Influence of nutrient sources and inclusion of mung bean on productivity, soil fertility and profitability of organic rice-wheat cropping system. Building Organic Bridges, at the Organic World Congress, 255-257.

Muhhammad, H., Zaman A., Khalil S.K. and Shah Z. 2014. Effect of beneficial microbes (BM) on the efficiency of organic and inorganic $\mathrm{N}$ fertilizers on wheat crop. Sarhad Journal of Agriculture, 30(1):7-13.

Sial, R.A., Chuadhary, E.H. Hussain, S. and Naveed, M. 2007. Effect of organic manures and chemical fertilizer on grain yield of wheat. Soil and Environment. 26(2): 130-133.

Soleimanzadeh, H., and Gooshchi F 2013. Effects of Azotobacter and nitrogen chemical fertilizer on yield and yield components of wheat (Triticum aestivum L.). World Applied Sciences Journal, 21(8):1176-1180.

\section{How to cite this article:}

Abhimanyu Yadav, Adesh Kumar, Ved Prakash, Neeraj Kumar, Ashutosh Tiwari and Yadav, R.K. 2017. Effect of Integrated Nutrient Management on Soil Properties, Yield Attributes and Yield of Wheat (Triticum aestivum L.). Int.J.Curr.Microbiol.App.Sci. 6(10): 225-228. doi: https://doi.org/10.20546/ijcmas.2017.610.028 